\title{
Administrating and Resolving the Traveler's Complaints with the use of Robotic Process Automation
}

\author{
${ }^{1}$ Anjali*, ${ }^{2}$ Jasminder Kaur Sandhu, ${ }^{3}$ Deepam Goyal \\ ${ }^{1,2,3}$ Chitkara University Institute of Engineering and Technology, \\ Chitkara University, Punjab, India \\ 1anjali@chitkara.edu.in*,2jasminder.sandhu@chitkara.edu.in, \\ 32deepam.goyal@chitkara.edu.in
}

\begin{abstract}
Robotic Process Automation (RPA) technology is used to automate the tasks and create the software bots. Actually RPA is that technology which mimic the actions of humans step by step to automate the entire process. There are several tools for RPA such as Blueprism, Automation Anywhere, Uipath and Microsoft Power Automation. These tools are used to identify the end to end business process and need to create the code that will describe the business process and run the commands. Presently, Automation process is used in several fields such as accounting and finance, in travel bookings, Traveling payment refund, managing and resolving the complaints of the customers, hotel inventories, etc. But this paper is based on to managing the customer complaints that are faced during their travel time with the use of Automation process. Process of Automation is very well now a days, to do everything very quickly and with the better way.
\end{abstract}

Keywords: Robotic Process Automation; Travel Complaints; Travel Agents; Tickets; Power Automate.

\section{Introduction}

Travel agents deals with the customer complaints that are faced during their travel. For tracking the customer complaints, the Digital Automation System is used which solves the potential issues. The Process of Tracking the Complaints is described in figure1. Migrating to paperless contracts and interacting with the customers online automatically includes tasks such as:

- Prioritizing the traveller complaints according to types of complaints, complaints urgency, etc.

- Managing the workflow by the travel team members and monitoring their progress of the complaints. Automatically managing the complaints quickly and accurately. 

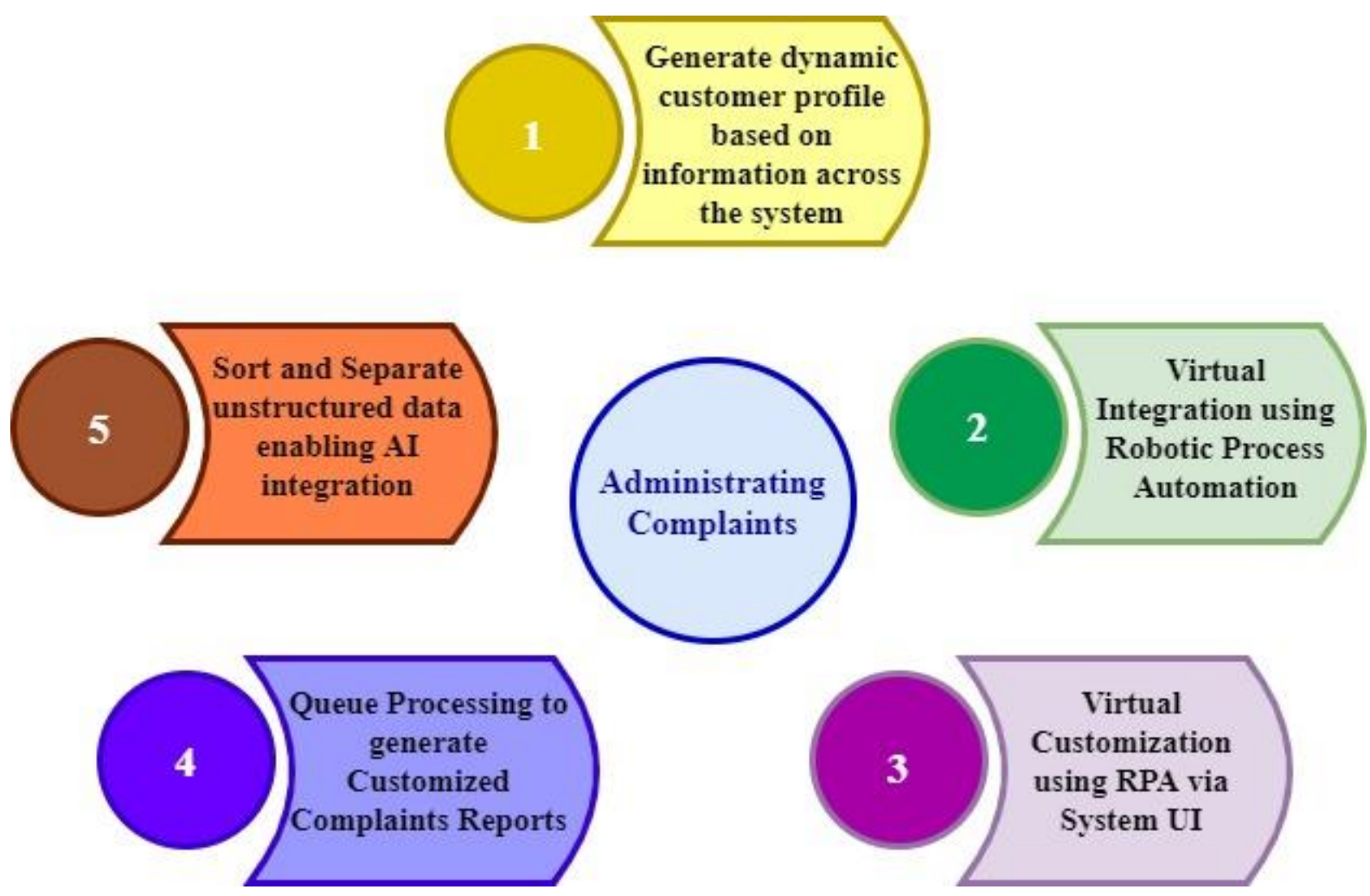

Figure 1: Overview of tracking the customer complaints

The Complaints management system intakes data from different sources to create tickets that will be utilized by the complaints processes. In this process, customer support system tracks the service requests of the customers and also interact with them to resolve their issues. An automatic system is used for resolving the issues of all the customers.

\section{Robotic Process Automation (RPA) and It's Working}

RPA is an automation mechanism that grants anyone to construct computer software. It is a kind of robot to integrate and emulate the behaviour of a person's interaction along with the digital system to implement a business process. Also, it interacts with technology to accomplish the tasks. Robotic Process Automation will automate the whole process and perform several tasks with bots such as extracting, reading, and storing the files, monitoring events, making proper documents, and sending confirmations [12]. It refers to the process of performing procedures that are software-based, complete tasks or processes with better efficiency and consume less time to do repetitive tasks [16]. The working of Robotic Process Automation is described in figure2. 


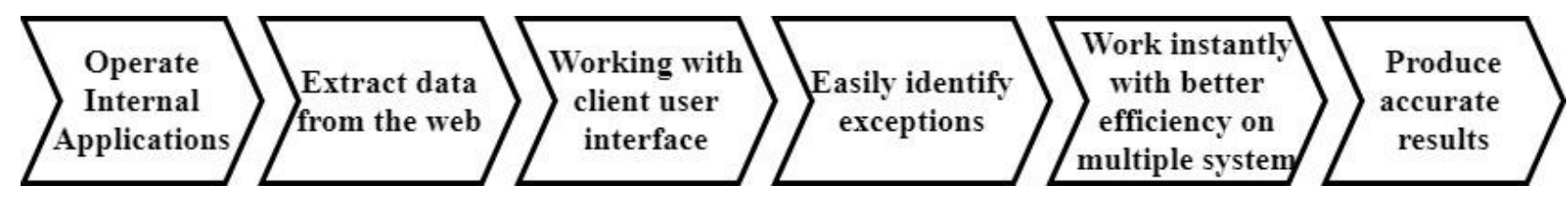

Figure 2: Working of RPA

To improve the decision - making part of bots, it contains certain Artificial Intelligence techniques. Also, for training the agents using computer vision or Machine Learning as well as RPA is a data centralized platform for controlling and maintaining the bots.

\subsection{Robotic Process Automation Tools}

Robotic Process Automation is used to automate the task routes within the platform that are performed by a company's client. It is a codeless development environment and non-developers can also easily do all the tasks or create bots. It is an alternative way to build the workflows and record actions that is performed by humans using several tools in RPA such as BluePrism, Automation Anywhere, Microsoft Power Automation, UiPath. These are described as follows:

2.1.2. Automation Anywhere: Automation Anywhere automates the end to end business processes. The components of Automation Anywhere are Bot creator, Control Room, and Bot runner. Bot creator is used to describe the business processes, then create the bots and complete process of the bot and finally need to upload on the control room. Control Room handles and controls the entire process of automation and contains the bot analytics that executes inside the bot runner and confirms the entire status of execution. Bot runner can run multiple bots at the same time parallel $[5,16]$.

2.1.2. BluePrism: It's an RPA tool which acts as a central manager of the entire automation process, and controls all the business operations. It has the ability to work on any platform with high speed execution. RPA promotes the use of software robots rather than humans. Users also want to do all complex tasks with the use of automation tools instead of it doing manually $[6,14,16]$. According to the competitors, it has been compliance, security, scalability, resilience and flexibility. Without any manual interference, it can operate and automate entire tasks.

2.1.3. Microsoft Power Automation: Microsoft Power Automation is an automation platform. It is a cloudbased software that allows to create an automated workflow and task across the particular applications and services without the help of the developers. Also, it can synchronize files, get notifications, and collect data. The platform is used to reduce the repetitive manual work. To create a flow the users specifies what actions should be taken and when specific event will occur. Virtually all the automated flows inception with triggers an event and an action with response to the event. 


\section{Literature Review}

Robotic Process Automation is developing the automation of several business processes tasks in the Travel, tourism sector to enhance the future.

In the field of tourism sector, Intelligent Automation is used in various areas that is assessing an impact of automation, creating sustainable future, beneficial of artificial intelligence for designing and facilitating adoption along with intelligent system. Process of adoption has been very constructive for industry purpose but according to the requirements of robust artificial intelligent system for further research. It ensures the implementation of this automation process for the development via travel and tourism [1].

Digital Automation System was popular example in the business enterprises for creating an interactive the business tasks for improving the skills of the travel agents [2]

Then, it is required to introduce automation and AI techniques in the process finance and accounting. The automated process is leads to standardize the certain process along with lower error rates, cost savings, documentation process and report generation quality [3].

Automation system was used to predict the demand of hotel bookings and for making better decisions for rejecting and accepting. This systematic process of predicting hotel bookings, reduces the rate of cancellation and increases the accounting tasks [4].

In the field of automation process, there are several technologies such as Machine Learning, Artificial Intelligence, Robotic Process Automation, Industrial Robots, Business Process Outsourcing and Virtual Assistance. These technologies consider, the ability of machines for think according to the human's behaviour [5].

Automation process is becoming an important part of any business enterprise including invoice processing, recruitment process, employee payroll, onboarding accounts, report creation and inventory management. This technology was improve the quality of work, get services $24 * 7$ hours, increase the productivity, reduce paper work and done many repetitive tasks automatically [6].

In paper [7], RPA was a kind of robots in which bots represents software agents via mimicking the human actions and reduce the workload of human workforce to enhance efficiency of the process to automate Sociotechnical implications, Implementation of methodological support and maximize analytical capabilities.

With the enhancement of Artificial Intelligence. Machine learning and Automation destination management the need is to predict the whole process [8].

In the paper [9], they were studied various other features of Robotic Process Automation such as the mouse functions, keys functions and sequence of images that was stored with the timestamps. In this technique analyze image process that changed into the task model to evaluate the knowledge of back end team members. Example, fingerprint and OCR (Optical Character Recognition).

RPA is a kind of software robot, it indicates the performance of the employees that is conducted via robots. This technique used to reduce the human work and paper work and also done repetitive tasks very quickly with less errors. It improves with the use of artificial intelligence, cognitive capabilities, contextual learning and some other tasks that was performed via software agents instead of human workers [10]. 
Several insurance companies like car, property, health and travel insurances were manage various policies as well as handle claim processing with the use of automation process. This process done repetitive tasks very quickly and easily such as increase the growth of meetings, customer services, maintain the competitive advantage and profit expectations in the market of insurance [11].

Several problems faced in the field of human resource, finance and supply chain departments like lot of data entry work with more error rates, significant rework and non -integrated legacy system. These problems handled very easily with the use of Automation process that integrate with Machine learning and artificial intelligence [12].

Travel and Tourism started the use of Automation in the system of delivery robots, conveyor restaurants, chatbots, robot concierge, kiosks and self-service systems for check-in and check-out. After that use of robotics in ATM (Banking Industry) has changed the way of customer's experiences [13].

RPA in multiple business contexts that is building a mature automation capability, strategy of automation service to implicate the decision and risks mitigation [14]. After that OpusCapita company offers outsourcing services and financial processes to large and medium sized companies. It is comprehend on the process of order to pay and purchase, to pay in finance and accounting automation [15].

RPA refer to the use of this technology to automate the process of Autonomic computing with the use of Artificial Intelligence and the two approaches that are IT - centric and Business process centric [16].

In the field of robotic process automation, Table 1. Compares the different techniques reported in the literature.

Table 1: Comparison of several previous approaches

\begin{tabular}{|c|c|c|l|}
\hline Ref.No. & Year & Techniques & \multicolumn{1}{c|}{ Summary } \\
\hline$[1]$ & 2020 & $\begin{array}{c}\text { Intelligent } \\
\text { Automation, } \\
\text { Robotics, } \\
\text { Artificial Intelligence }\end{array}$ & $\begin{array}{l}\text { Intelligent Automation in } \\
\text { Travel and tourism for } \\
\text { accessing, facilitating the } \\
\text { future of artificial } \\
\text { intelligence. Automation } \\
\text { used in methodologies and } \\
\text { several disciplinary } \\
\text { prospects were expected } \\
\text { to relevant knowledge } \\
\text { production policy. }\end{array}$ \\
\hline$[2]$ & 2020 & $\begin{array}{l}\text { Artificial Intelligence, } \\
\text { Machine Learning, } \\
\text { RPA }\end{array}$ & $\begin{array}{l}\text { To overcome the problem } \\
\text { of documentation process } \\
\text { and cognitive intelligence } \\
\text { capabilities Robotic } \\
\text { process automation is } \\
\text { used. }\end{array}$ \\
\hline
\end{tabular}




\begin{tabular}{|c|c|c|c|}
\hline [3] & 2019 & $\begin{array}{c}\text { Knowledge } \\
\text { Representation (KR) } \\
\text { technique: } \\
\text { 1. Rules based } \\
\text { system } \\
\text { 2. Semantic network } \\
\text { Artificial Intelligence }\end{array}$ & $\begin{array}{l}\text { Implementation of } \\
\text { Robotic Process } \\
\text { Automation for } \\
\text { optimizing and } \\
\text { standardizing the tasks. } \\
\text { To automate the assertive } \\
\text { processes, that are } \\
\text { repeated, structured and } \\
\text { rule-based. It improve the } \\
\text { documentation process } \\
\text { and give more accurate } \\
\text { results. }\end{array}$ \\
\hline$[4]$ & 2019 & $\begin{array}{l}\text { Machine Learning, } \\
\text { Robotic Process } \\
\text { Automation, }\end{array}$ & $\begin{array}{l}\text { Automation system was } \\
\text { used to predict the } \\
\text { demand of hotel bookings } \\
\text { and for making better } \\
\text { decisions for rejecting and } \\
\text { accepting. Also predicted } \\
\text { how to reduce the } \\
\text { percentage of cancellation } \\
\text { of hotel bookings. }\end{array}$ \\
\hline [5] & 2019 & $\begin{array}{l}\text { Intelligent Process } \\
\text { Automation, } \\
\text { Business } \\
\text { Organization, } \\
\text { BluePrism, } \\
\text { Automation } \\
\text { Anywhere, Uipath }\end{array}$ & $\begin{array}{l}\text { To configure the } \\
\text { performance of human } \\
\text { tasks in physical robots } \\
\text { wandering with Robotic } \\
\text { process automation } \\
\text { technologies. }\end{array}$ \\
\hline [6] & 2019 & $\begin{array}{l}\text { Automation Process, } \\
\text { Deep Learning, } \\
\text { Artificial Intelligence }\end{array}$ & $\begin{array}{l}\text { Ability to automate the } \\
\text { tasks of inventory } \\
\text { management and other } \\
\text { financial services with the } \\
\text { information of employee's } \\
\text { status changes, payroll } \\
\text { and then create a report } \\
\text { with better accuracy. }\end{array}$ \\
\hline [7] & 2019 & $\begin{array}{l}\text { Intelligent Process } \\
\text { Automation, } \\
\text { Cognitive Computing, } \\
\text { Machine Learning, } \\
\text { Block chain }\end{array}$ & $\begin{array}{l}\text { To enhance efficiency of } \\
\text { the process to automate } \\
\text { Sociotechnical } \\
\text { implications, } \\
\text { Implementation of } \\
\text { methodological support } \\
\text { and maximize analytical } \\
\text { capabilities. }\end{array}$ \\
\hline$[8]$ & 2019 & $\begin{array}{l}\text { Automation Process, } \\
\text { Robotics, } \\
\text { Artificial Intelligence }\end{array}$ & $\begin{array}{l}\text { To automate the process } \\
\text { of Travel and tourism } \\
\text { demand and supply goods } \\
\text { with the perspective of the } \\
\text { destination management. }\end{array}$ \\
\hline
\end{tabular}




\begin{tabular}{|c|c|c|c|}
\hline [9] & 2019 & $\begin{array}{l}\text { Business Process } \\
\text { Outsourcing, } \\
\text { RPA }\end{array}$ & $\begin{array}{l}\text { Evaluate the process of } \\
\text { Robotic Process } \\
\text { Automation to increase } \\
\text { the knowledge of back } \\
\text { end team members in the } \\
\text { field of image processing } \\
\text { system. }\end{array}$ \\
\hline [10] & 2018 & $\begin{array}{l}\text { Machine Learning, } \\
\text { Artificial intelligence } \\
\text { techniques }\end{array}$ & $\begin{array}{l}\text { To emphasize the thinking } \\
\text { skills of higher order and } \\
\text { enhance the quality of } \\
\text { accounting with the use of } \\
\text { RPA. }\end{array}$ \\
\hline [11] & 2017 & $\begin{array}{c}\text { Artificial Intelligence, } \\
\text { Digital Automation } \\
\text { System, } \\
\text { Software Robotics }\end{array}$ & $\begin{array}{l}\text { To automate the financial } \\
\text { services for the better } \\
\text { efficiency and highlight } \\
\text { the main components of } \\
\text { Robotic process } \\
\text { automation. }\end{array}$ \\
\hline [12] & 2017 & $\begin{array}{l}\text { Business Process } \\
\text { Outsourced, } \\
\text { Automation Process }\end{array}$ & $\begin{array}{l}\text { To analyse the importance } \\
\text { of Robotic Process } \\
\text { Automation in the field of } \\
\text { Business Process } \\
\text { Outsource and Shared } \\
\text { service centre's. }\end{array}$ \\
\hline [13] & 2017 & $\begin{array}{c}\text { Robots, } \\
\text { Artificial Intelligence, } \\
\text { Service Automation }\end{array}$ & $\begin{array}{l}\text { To investigate the process } \\
\text { of quality of service } \\
\text { request, HRM, hospitality } \\
\text { layout and reduce cost } \\
\text { into the tourism and travel } \\
\text { with the use of Robotic } \\
\text { Process Automation. }\end{array}$ \\
\hline [14] & 2017 & $\begin{array}{l}\text { Global Business } \\
\text { Service, } \\
\text { Business Process } \\
\text { Outsourcing, } \\
\text { RPA }\end{array}$ & $\begin{array}{l}\text { Implementation of RPA in } \\
\text { multiple business contexts } \\
\text { i.e. building a mature } \\
\text { automation capability, } \\
\text { strategy of automation } \\
\text { service to implicate the } \\
\text { decision. }\end{array}$ \\
\hline [15] & 2016 & $\begin{array}{l}\text { Robotic Process } \\
\text { Automation }\end{array}$ & $\begin{array}{l}\text { The focus of OpusCapita } \\
\text { to comprehend on the } \\
\text { process of order to pay } \\
\text { and purchase; to pay in } \\
\text { finance and accounting } \\
\text { automation. }\end{array}$ \\
\hline [16] & 2015 & $\begin{array}{c}\text { Artificial Intelligence, } \\
\text { Autonomic computing } \\
\text { techniques, } \\
\text { RPA }\end{array}$ & $\begin{array}{l}\text { Ability to automate the } \\
\text { process of Autonomic } \\
\text { computing with the use of } \\
\text { Artificial Intelligence and } \\
\text { the two approaches that } \\
\text { are IT - centric and } \\
\text { Business process centric. }\end{array}$ \\
\hline
\end{tabular}




\section{Challenges}

There are many problems that are faced customers during travel and complaining an action- oriented approach to a state of the dissatisfaction with the services. To overcome the issue of customer complaints, RPA is used and it focusses on the critical customer issues in simple and quick manner. To understand the customer complaints is a very crucial part for every team member. The Automation system was used to predict the demand for hotel bookings and for making better decisions for rejecting and accepting. This systematic process of predicting hotel bookings reduces the rate of cancellation and increases the accounting tasks [4]. Robotic Process Automation improve the experience of the customers across multiple industries, reduce the cost and regulatory compliances. On the reacceptance of the customer complaints instantly take an action for the solution of issues that are faced by the customer

\section{Process Automation Strategy in Travel Industry}

Travelers need to consult with travel agency to a customized the experience for vacations to select and choose best destinations.

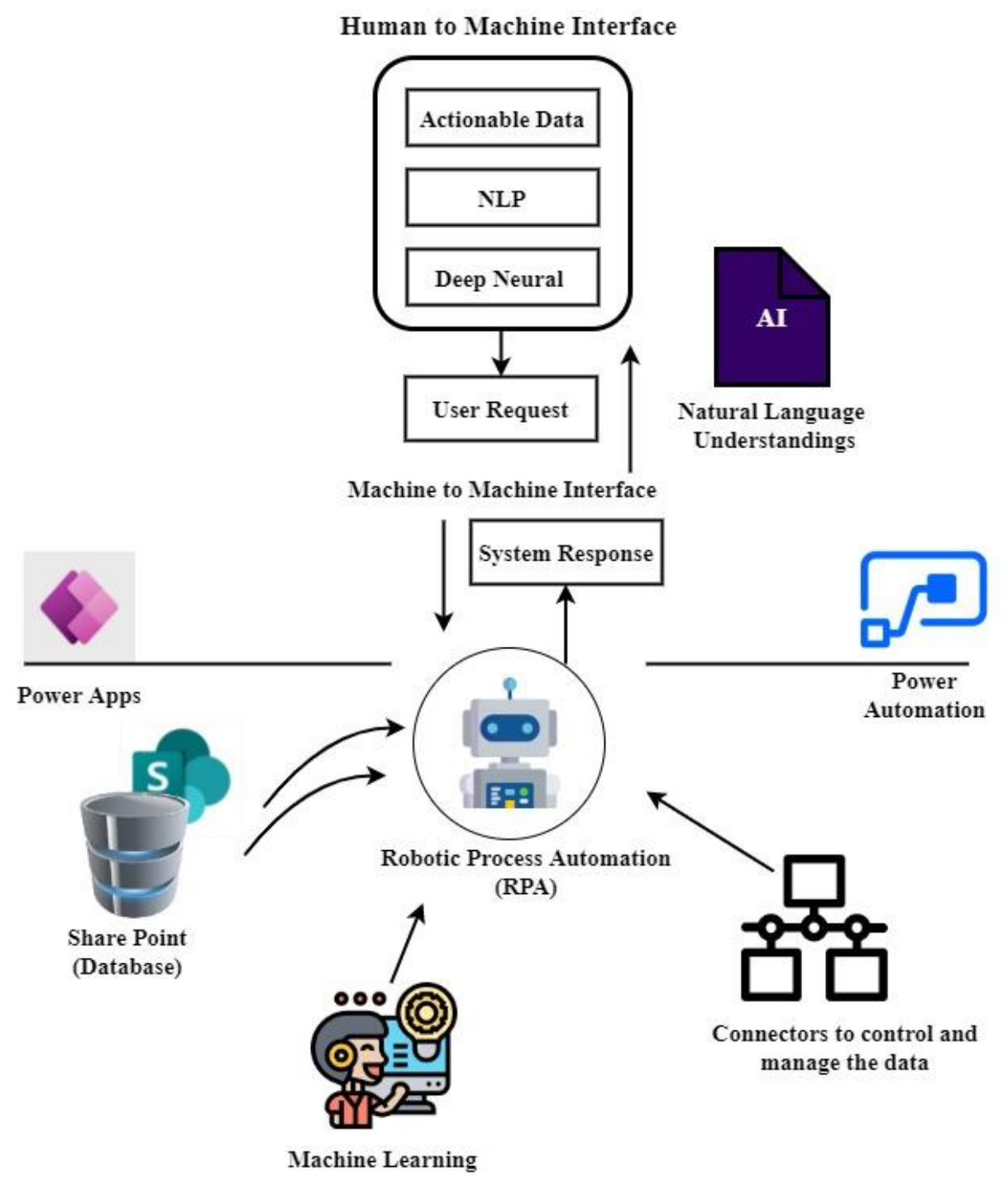

Figure 3: Architecture of Automation Process along with AI 
Here, use RPA to automate all the system as repetitive tasks, time consuming tasks and rule based processes like tracking payments, processing orders, digitizing paper work, communicating with customers and manage entire information regarding travel.

In the Figure. 3 are used to depict the implementation of AI driven functionalities along with RPA are described as:

1. Initially capturing the interface of user that are used to allow for fetching the user requests such as multiple languages, extract contextual data, tokenization, etc.

2. Use of software robots to handle time consuming and repetitive tasks with the automation systems for example creating and sending reports for travelers.

3. Software robots specifies the data structure performance and efficiency, availability, exception handling and monitoring.

4. To handle or manage all the working of travel agency use RPA to reduce the human work and human errors.

\section{Conclusion}

Robotic process automation reduce the human errors in both front and back end processes and improve the journey of travelers. Reduction in regulatory compliances of risks and increase the processing speed. Implementation of automation process to analyse the data from task technology, suitability of documentation, develop tasks in the structure of governance include reforms the constitutional controls and outcomes of the resulting performance. So the solution of this process is that software bots will perform entire tasks very easily and quickly that the employees are doing in a repetitive manner. Benefit is that, Since the robot will do these tasks, it can do task in a continuous manner so time is reduce, cost will also be reduce and it can produce more accurate results because bots will do the tasks with sequence of steps.

\section{REFERENCES}

[1] Tussyadiah, I. (2020). A review of research into automation in tourism: Launching the Annals of Tourism Research Curated Collection on Artificial Intelligence and Robotics in Tourism. Annals of Tourism Research, 81, 102883.

[2] Rizk, Y., Isahagian, V., Boag, S., Khazaeni, Y., Unuvar, M., Muthusamy, V., \& Khalaf, R. (2020, September). A Conversational Digital Assistant for Intelligent Process Automation. In International Conference on Business Process Management (pp. 85-100). Springer, Cham.

[3] Kokina, J., \& Blanchette, S. (2019). Early evidence of digital labor in accounting: Innovation with Robotic Process Automation. International Journal of Accounting Information Systems, 35, 100431.

[4] Antonio, N., de Almeida, A., \& Nunes, L. (2019). An automated machine learning based decision support system to predict hotel booking cancellations. An automated machine learning based decision support system to predict hotel booking cancellations, (1), 1-20.

[5] Ansari, W. A., Diya, P., Patil, S., \& Patil, S. (2019, April). A review on robotic process automationthe future of business organizations. In 2nd International Conference on Advances in Science \& Technology (ICAST). 
[6] Madakam, S., Holmukhe, R. M., \& Jaiswal, D. K. (2019). The future digital work force: robotic process automation (RPA). JISTEM-Journal of Information Systems and Technology Management, 16.

[7] Syed, R., Suriadi, S., Adams, M., Bandara, W., Leemans, S. J., Ouyang, C., ... \& Reijers, H. A. (2020). Robotic process automation: contemporary themes and challenges. Computers in Industry, 115, 103162.

[8] Ivanov, S., \& Webster, C. (2020). Robots in tourism: A research agenda for tourism economics. Tourism Economics, 26(7), 1065-1085.

[9] Jimenez-Ramirez, A., Reijers, H. A., Barba, I., \& Del Valle, C. (2019, June). A method to improve the early stages of the robotic process automation lifecycle. In International Conference on Advanced Information Systems Engineering (pp. 446-461). Springer, Cham.

[10] Moffitt, K. C., Rozario, A. M., \& Vasarhelyi, M. A. (2018). Robotic process automation for auditing. Journal of Emerging Technologies in Accounting, 15(1), 1-10.

[11] Lamberton, C., Brigo, D., \& Hoy, D. (2017). Impact of Robotics, RPA and AI on the insurance industry: challenges and opportunities. Journal of Financial Perspectives, 4(1).

[12] Anagnoste, S. (2017, July). Robotic Automation Process-The next major revolution in terms of back office operations improvement. In Proceedings of the International Conference on Business Excellence (Vol. 11, No. 1, pp. 676-686). Sciendo.

[13] Ivanov, S. H., \& Webster, C. (2017). Adoption of robots, artificial intelligence and service automation by travel, tourism and hospitality companies-a cost-benefit analysis. Artificial Intelligence and Service Automation by Travel, Tourism and Hospitality Companies-A CostBenefit Analysis.

[14] Willcocks, L., Lacity, M., \& Craig, A. (2017). Robotic process automation: strategic transformation lever for global business services?. Journal of Information Technology Teaching Cases, 7(1), 1728.

[15] Asatiani, A., \& Penttinen, E. (2016). Turning robotic process automation into commercial successCase OpusCapita. Journal of Information Technology Teaching Cases, 6(2), 67-74.

[16] Barnett, G. (2015). Robotic process automation: adding to the process transformation toolkit. White paper IT0022-0005, Ovum Consulting 